\title{
Workability and Compressive Strength for Concrete With Coconut Shell Aggregate
}

\author{
Alif Syazani Leman ${ }^{1}$, Shahiron Shahidan ${ }^{1, a}$, Mohd. Yazid Yusuf ${ }^{1}$, Sharifah Salwa Mohd Zuki ${ }^{1}$, and Noor Aina Misnon ${ }^{2}$ \\ ${ }^{1}$ Faculty of Civil \& Environmental Engineering, Universiti Tun Hussein Onn Malaysia 86400 Batu Pahat, Johor, Malaysia \\ ${ }^{2}$ Department Of Civil Engineering, Universiti Pertahanan Nasional Malaysia, 57000 Kuala Lumpur, Malaysia
}

\begin{abstract}
This study was conducted to investigate the compressive strength and workability of concrete added with coconut shells. Comparisons were made between conventional concrete with concrete mix coconut shell. In this study, the concretes were mixes with coconut shell by percentage of weight concrete which is $0 \%, 5 \%$, and $10 \%$. The coconut shell has been crushed first, then it was sieved, to get the optimum size which, that retained on the $5 \mathrm{~mm}$ sieve and passing $10 \mathrm{~mm}$ sieve. Experimental tests conducted in this study are slump test and compressive test. The results from this study are workability of concrete added with $0 \%$ and $5 \%$ of coconut shell has medium degree of workability compared to concrete added with $10 \%$ that has low workability. For the compressive strength, the concrete added with $5 \%$ and $10 \%$ of coconut shell has lower strength compared with normal concrete.
\end{abstract}

\section{Introduction}

Concrete is a material produced from several materials such as cement, coarse and fine aggregates, and water mixture [1][2]. The application of concrete material in construction industry was highly demand which growing rapidly demonstrates the need for various types and properties of concrete to meet the diverse needs of the user [3]. However, due to the influx of construction projects that use a lot of concrete as the main material of construction, huge amounts of natural resources are required to make concrete [4][5]. As an alternative solution, the agricultural waste is the best way to reduce the raw materials used in construction industry and thus helping to reduce pollution caused by disposal of agricultural waste [6][7].

Coconut grown in over 86 countries worldwide and generates more than 54 billion nuts per annum [8]. However, after the coconut is scraped out, the shell is usually discarded as waste [9]. With the use of coconut shell as a replacement material in the construction industry, indirectly reduce the costs production of concrete and the disposal of waste [10][11]. The used of coconut shell in the manufacturing of concrete, indirectly creating new inventions in order to improve the concrete manufacturing industry as well as save costs and reduce solid waste disposal. Coconut shell is often used as a composite in concrete because of the characteristics found in it better than material that commonly used in production of concrete. Besides, coconut shell is potential material for the development of new composite material in concrete mix design because of their high strength and modulus properties [12]. However, further research is needed for better understanding of the behavior of coconut shell in concrete. Thus, the aim of this work is to provide more data on the strength of concrete with coconut shell at different percentage coconut shell used. Furthermore, in this study the workability of concrete with coconut shell was also investigated.

\section{Coconut Shell Properties}

Coconut shell may offer itself as a potential construction material in the field of construction industries and would solve the environmental problem of reducing the generation of solid wastes simultaneously. Coconut shell is often used as a composite in concrete because of the characteristics found in it better than material that commonly used in production of concrete. Coconut shell has high strength and modulus properties along with the added advantage of high lignin content. The shell also absorbs less moisture due to its low cellulose content [13]. Besides, the surface texture of the coconut shell was fairly smooth on concave and rough on concave faces. In addition, coconut shells are used in the production of activated carbon due to hardness and high carbon content [14]. Thus, coconut shells are fairly enough to get workability same or better than normal material used in concrete. The properties of coconut shells were compared with crushed granite and oil palm shell (Table 1).

\footnotetext{
a Corresponding author: shahironshahidan@gmail.com
} 
Table 1: Properties of coconut shell, oil palm shell, crushed granite and river sand (Gunasekaran, Kumar, \& Lakshmipathy, 2011)

\begin{tabular}{|c|l|l|l|l|l|}
\hline SI.No & \multicolumn{1}{|c|}{$\begin{array}{c}\text { Physical and mechanical } \\
\text { properties }\end{array}$} & $\begin{array}{c}\text { Coconut } \\
\text { shell }\end{array}$ & $\begin{array}{c}\text { Oil palm } \\
\text { shells }\end{array}$ & $\begin{array}{c}\text { Crushed } \\
\text { granite }\end{array}$ & River sand \\
\hline $\mathbf{1}$ & Maximum size $(\mathrm{mm})$ & 12.5 & 12.5 & 12.5 & - \\
\hline $\mathbf{2}$ & Moisture content $(\%)$ & 4.20 & - & - & - \\
\hline $\mathbf{3}$ & Water absorption $(24 \mathrm{~h})(\%)$ & 24.00 & 23.32 & 0.50 & - \\
\hline $\mathbf{4}$ & Specific gravity & $1.05-1.20$ & 1.17 & 2.82 & 2.57 \\
\hline $\mathbf{5}$ & SSD $^{\mathrm{a}}$ apparent & $1.40-1.50$ & - & 2.86 & - \\
\hline $\mathbf{6}$ & Impact value (\%) & 8.15 & 7.86 & 12.40 & - \\
\hline $\mathbf{7}$ & Crushing value (\%) & 2.58 & - & 6.30 & - \\
\hline $\mathbf{8}$ & Abrasion value $(\%)$ & 1.63 & 4.80 & 1.85 & - \\
\hline $\mathbf{9}$ & Bulk density $\left(\mathrm{kg} / \mathrm{m}^{3}\right)$ & 650 & 590 & 1650 & - \\
\hline $\mathbf{1 0}$ & Compacted loose & 550 & - & 1450 & - \\
\hline $\mathbf{1 1}$ & Fineness modulus & 6.26 & 6.24 & 6.94 & 2.56 \\
\hline $\mathbf{1 2}$ & Shell thickness $(\mathrm{mm})$ & $2-8$ & $1.5-2.5$ & - & - \\
\hline
\end{tabular}

\section{Behaviour Of Concrete With Coconut Shell}

Recently efforts have been made on the use of agricultural waste, coconut shell as composite materials to produce structural concrete [9]. In addition, the use of this shell has brought benefits in term of economic and environmental. Apart from that the ultimate bond strength of coconut shell as aggregate concrete under all type of curing conditions was much higher compared to the theoretical bond strength as per BS 8110 and IS 456 [10]. Besides, bonding between cement paste and coconut shell shows that the bond appears to be better [15]. In addition, the use of coconut shell in the production of concrete has better workability, compressive strength, flexural strength, slip tensile strength, impact resistance, bonding property of coconut shell have been studies, discussed and published already; all these properties are comparable with normal and other lightweight concrete [16]. Apart from that, from shell concrete beam behaviors under flexural, shear and torsion show that improvement and better result compare to normal concrete [17][18]. However, not all parameters of concrete experiments conducted using coconut shells can rival the result of normal concrete.

\section{Experimental Works}

In this research, it consists of 2 major part of testing in fresh concrete. There are slump test for workability and compressive test for the concrete strength. This investigation were prepare of 27 concrete cubes size of $150 \mathrm{~mm} \times 150 \mathrm{~mm} \times 150 \mathrm{~mm}$, with a grade C35. The detail percentage of coconut shell as presented in the next subtopic.

\subsection{Material Preparation}

The freshly discarded coconut shell was obtained from local processing oil mills were close to the study area. Coconut shell obtained has been cleaned from impurities. It was obtained in the already cracked and oil extracted form. Coconut shell was broken into a small chips manually using hammer before crushed it into small pieces. The fibrous outer parts of the nut were needed to be removed first, and then coconut shell is crushed by a crusher. Before being put into mix, crushed coconut shell were sieved by size to be used in concrete. The crushed of coconut shell was graded by using shaker machine to get the optimum size which retained on the $5 \mathrm{~mm}$ sieve and passing $10 \mathrm{~mm}$ sieve. In this research, percentage of coconut shell used in concrete was $0 \%, 5 \%$ and $10 \%$. The percentage was calculated based on the weight of concrete. For other concrete mix constituents, such as cement, water, fine and coarse aggregates were obtained from Fkaas Laboratory, University Tun Hussien Onn Malaysia. The cement used as the binding agent was Ordinary Portland Cement. For coarse aggregates, the size used was which retained on the No.4 $(4.75 \mathrm{~mm})$ sieve where fine aggregate are aggregate passing No.4 $(4.75 \mathrm{~mm})$ sieve and predominately retained on the No.200 $(700 \mu \mathrm{m})$. The potable water available in Fkaas Lab premises was used for mixing and curing

\subsection{Mix Proportions}

There are three mixes were employed. First, control mix which is concrete without coconut shell was made by using a basic material such as Ordinary Portland cement, fine and coarse aggregates and water. Normal concrete sample made are as comparative experiments between coconut shells concrete. Then, mix of concrete added 
with 5 and 10 percentages of coconut shell was made. The details of the mixture proportions used for the concrete are shown in Table 2 . Every percent of coconut shell used, curing period and also coconut shell size used requires at least three cubes to get the average value for compressive strength test. Since all material has been prepared, the concrete work can be carried out by using mixer. Then, after several minute and the concrete were mixed well, the mixture will pour into a mould with prescribed size.

Table 2: Mixture proportions

\begin{tabular}{|l|c|c|c|c|c|}
\hline Mixes & $\begin{array}{c}\text { Cement } \\
(\mathbf{k g})\end{array}$ & $\begin{array}{c}\text { Coarse } \\
\text { aggregate } \\
\text { (kg) }\end{array}$ & $\begin{array}{c}\text { Fine } \\
\text { aggregate } \\
\mathbf{s}(\mathbf{k g})\end{array}$ & $\begin{array}{c}\text { Water } \\
(\mathbf{k g} / \mathbf{L})\end{array}$ & $\begin{array}{c}\text { Coconut } \\
\text { shell } \\
(\mathbf{k g})\end{array}$ \\
\hline Control & 13.67 & 37.67 & 16.1 & 5.47 & 0.00 \\
\hline $\begin{array}{l}5 \% \\
\text { coconut } \\
\text { shell }\end{array}$ & 13.67 & 37.67 & 16.1 & 5.47 & 3.75 \\
\hline $\begin{array}{l}10 \% \\
\text { coconut } \\
\text { shell }\end{array}$ & 13.67 & 37.67 & 16.1 & 5.47 & 7.50 \\
\hline
\end{tabular}

\subsection{Testing Method}

This research was conducted of two major test, which is workability and compressive strength test. Workability Test; this test was performed according to procedures established by the BS 1881: Part 102: 1983. Firstly, the cone were cleaned and damped. Next, the mold placed on a smooth and flat surface. Then, the mold was placed on flat tray with a part of the sampling cone diameter of $200 \mathrm{~mm}$ at the top and concrete mix was filled into the mold of three layers. Each layer that was filled in must be compacted 25 times using tapping rod. Once completed, the top of the cone mold is flattened using spatula. Mold slowly lifted vertically upward and the slump value is recorded. The workability of the concrete can be determined by measuring the slump drop.

Compressive Strength Test; this test was performed according to procedures established by the BS 1881: Part 102: 1983. Details about concrete such as the size of the cube should be recorded first so that the result of tests conducted compactible with size of the cubes were tested. After the materials and machines available, this test was carried out. The test was conducted on $150 \mathrm{~mm} \times 150 \mathrm{~mm}$ $\mathrm{x} 150 \mathrm{~mm}$ cube specimen at 7,14 , and 28 days. The sample cubes were placed in the testing machine. Loading were applied on the sample until the sample fails, where the reading started to decline. The test was repeated conducted on another two more cubes and the value was taken as the average.

\section{Results And Discussions}

A comprehensive summary of the workability and strength properties of normal concrete and concrete with coconut shell added are represented in Table 3 and Figure 4. Result were presented through univariate analyzes. For this univariate analyzes, it include demographic data consisting of the strength and workability of concrete cube with crushed coconut shells.

\subsection{Workability Studies}

For concrete mix with $0 \%$ (Figure 1) and 5\% (Figure 2) of coconut shell that had $60.5 \mathrm{~mm}$ and $50.0 \mathrm{~mm}$ slump, these mixtures had medium of degree of workability. For concrete mix with $10 \%$ (Figure 3 ) of coconut shell that had $25.0 \mathrm{~mm}$ slump, this mixture had low degree of workability. From the result, show that if the percentage of coconut shell added increase, the degree of workability of concrete mix will decreased. This result may be happen because of coconut shell have relatively high water absorption compared to the conventional aggregates.

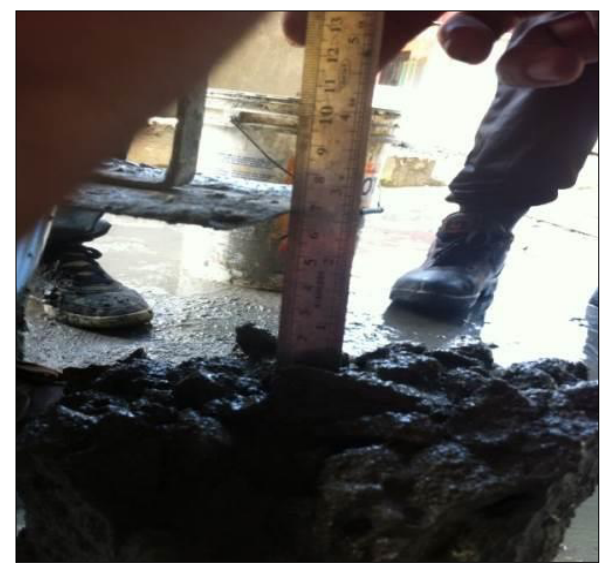

Figure 1: Concrete with $0 \%$ coconut shell

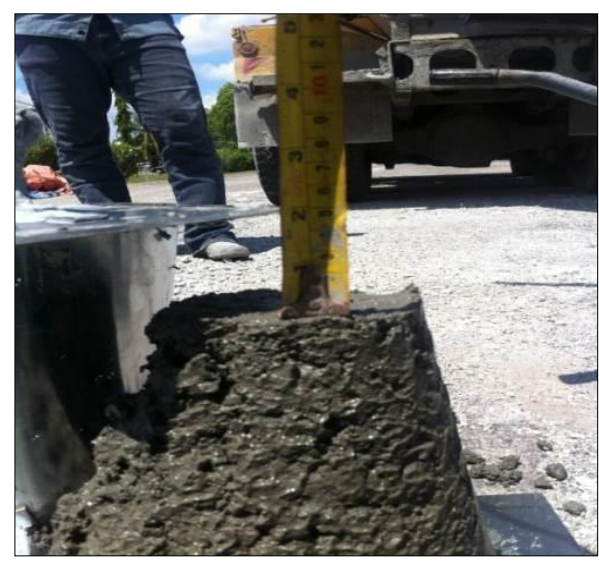

Figure 2: Concrete with 5\% added of crushed coconut shell 


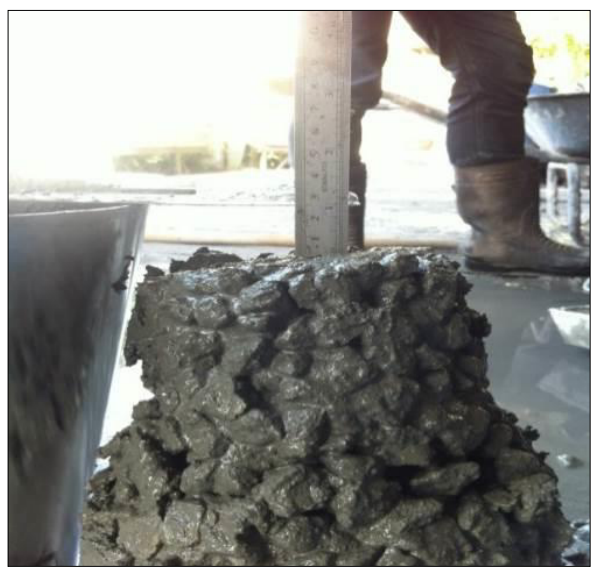

Figure 3: Concrete with $10 \%$ added of crushed coconut shell

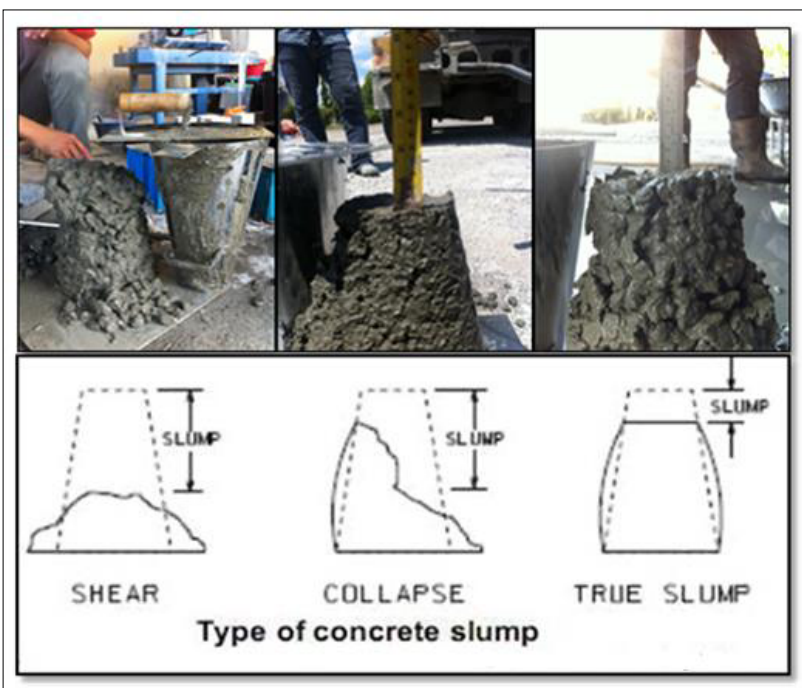

Figure 4: Comparison of slump test result with practical standard referring to BS 1881: Part 102: 1983

Table 3: Data of workability test

\begin{tabular}{|c|c|}
\hline Percentage Of Coconut Shell & Slump Reading \\
\hline $0 \%$ & $60.5 \mathrm{~mm}$ \\
\hline $5 \%$ & $50.0 \mathrm{~mm}$ \\
\hline $10 \%$ & $25.0 \mathrm{~mm}$ \\
\hline
\end{tabular}

\subsection{Compressive Strength}

The data of compressive strength and density for each sample were recorded and were representing in graph below in Figure 5 and Figure 6. This graph was shown all the data collected including the age of concrete tested and also by percentages of coconut shell added

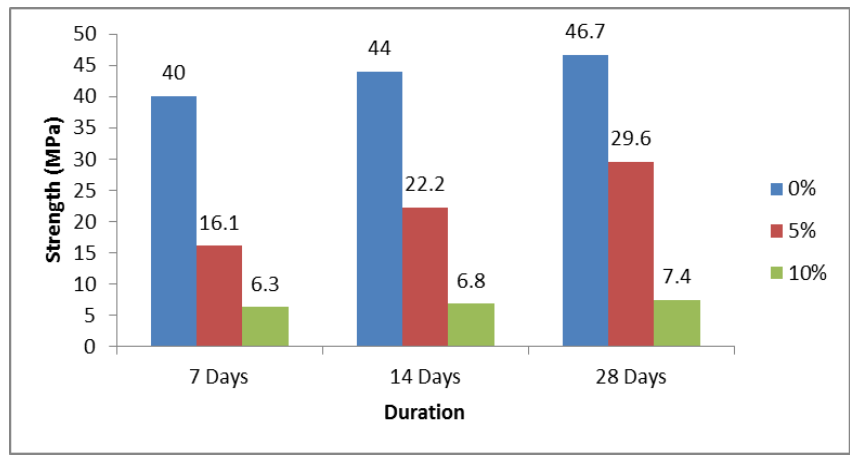

Figure 5: Graph of strength versus duration

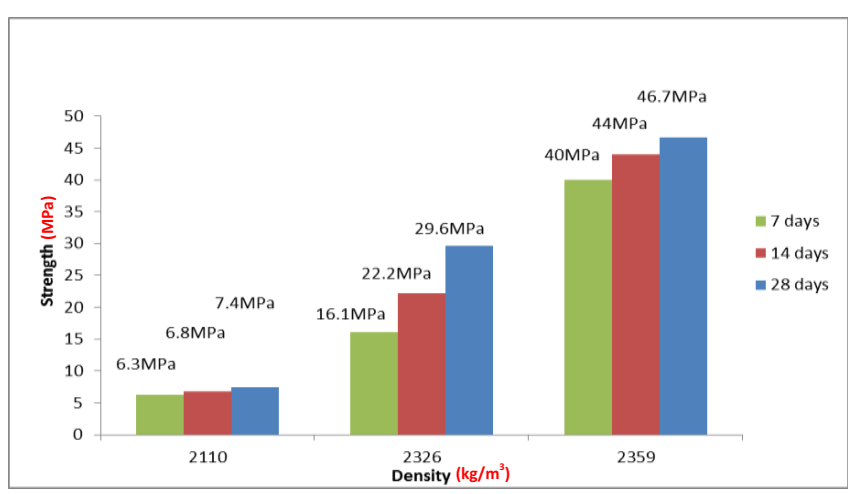

Figure 6: Graph of strength versus density

From the data collected, there was good relationship between the parameter. For concrete with $0 \%$ of coconut shell added or control concrete, the density of this sample is $2359 \mathrm{~kg} / \mathrm{m}^{3}$. In term of strength, the strength of concrete is increased follow by the age of concrete which is $40 \mathrm{MPa}$ for 7 days, $44 \mathrm{MPa}$ for 14 days and $46.7 \mathrm{MPa}$ for 28 days. For concrete added with $5 \%$ and $10 \%$ of coconut shells, the pattern of strength versus density is same with control concrete, which is the compressive strength of concrete increased when the density of concrete is increased. However, the strength of concrete specimen decreased when the percent of coconut shell added is increased. This may happen when the percent of coconut shell added are higher will decreasing the density of concrete. The decreasing value of the concrete strength while the percentage of coconut shell added into concrete increased happen maybe related to the workability of each concrete mix. The percentages of coconut shell added will decreased the degree of workability of concrete. Then, the lower degree of workability happens because of high water absorption in concrete. Therefore, while the level of water absorption of concrete is high, it will affect the strength of concrete. 


\subsection{Relationship Between Compressive Strength and Density}

In this study, the data of compressive strength and density for each sample were recorded. The data were representing in graph below in Figure 7(a) and Figure 7(b). This graph was shown all the data collected including the age of concrete tested and also by percentages of coconut shell added.

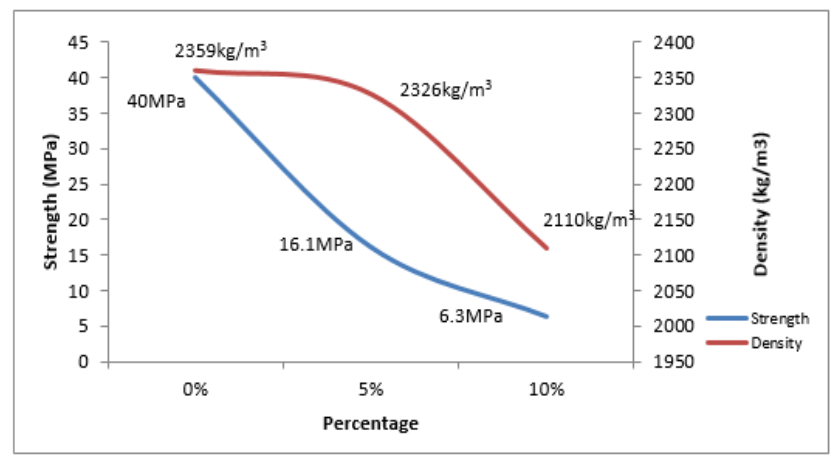

Figure 7(a): Graph of strength versus density for 7days

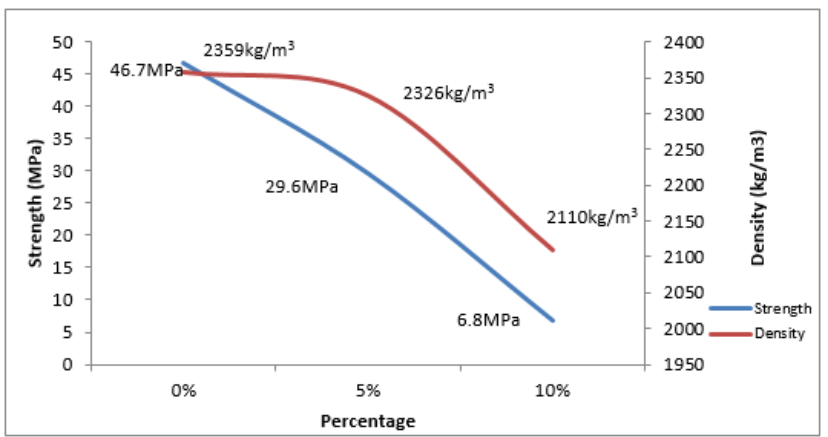

Figure 7(b): Graph of strength versus density for 28days

From the data collected, there was good relationship between the parameter. The compressive strength of concrete is increased when the density of concrete is increased. However, the strength of concrete specimen decreased when the percent of coconut shell added is increased. This may happen when the percent of coconut shell added are higher will decreasing the density of concrete. Although the densities of the concrete are more than $2000 \mathrm{~kg} / \mathrm{m}^{3}$, the compressive strength obtained is lower due to the high water absorption of the material. It shows that the hardened cement paste is less wellstructured and more porous when hydration proceeds at faster rate.

\section{Conclusions}

A comparative study of workability and strength of concrete added with coconut shell and compare it with normal concrete has been carried out. Generally, the compressive strength of concrete added with coconut shell decreased as the percentage of coconut shell added is increased. Same result goes to the workability test, the workability of concrete decreased as percent of coconut shell added in concrete is increased. Based on the result, some suggestions for improvement should be given in this study.

This is to ensure that the research can have more appropriate result and better data than before. Here are some of the recommendations:

a) The coconut shell must be cleaned first, remove it from anything that can affect the properties or strength of the coconut shell

b) The coconut shell may could be dry or soaked into water first to changes the properties of coconut shell

c) Coconut shell may be treated first by any kind of treated method before use in concrete

d) Changes the shape or size of coconut shell use in concrete mix

e) Use the different type of curing process

f) Added some of admixture that can improve the bonding between coconut shell and concrete

g) Mix the coconut shell with the different type of cement used.

\section{Acknowledgements}

The authors would like to thank Universiti Tun Hussein Onn Malaysia for Grant GPPS U449 and Grant Vot U523

\section{References}

1. M. Abdul Rahim, N. M. Ibrahim, Z. Idris, Z. M. Ghazaly, S. Shahidan, N. L. Rahim, L. A. Sofri, and N. F. Isa, "Properties of Concrete with Different Percentange of the Rice Husk Ash (RHA) as Partial Cement Replacement," Mater. Sci. Forum, vol. 803, pp. 288-293, (2014).

2. N. Md Nor, N. Muhamad Bunnori, A. Ibrahim, S. Shahidan, and S. N. M. Saliah, "An investigation on acoustic wave velocity of reinforced concrete beam in-plane source," in Proceedings - 2011 IEEE 7th International Colloquium on Signal Processing and Its Applications, CSPA 2011, 2011, pp. 19-22.

3. S. A. Kudus, N. M. Bunnori, S. R. Basri, S. Shahidan, M. N. M. Jamil, and N. M. Noor, "An Overview Current Application of Artificial Neural Network in Concrete," Adv. Mater. Res., vol. 626, pp. 372-375, 2012

4. S. R. Abdullah, W. R. Wan Zainal Abidin, and S. Shahidan, "Strength of Concrete Containing Rubber Particle As Partial Cement Replacement," MATEC Web Conf., vol. 47, pp. 2-5, 2016.

5. M. A. Rahim, Z. Ghazaly, R. Nurazira, R. Mamat, M. A. Azizan, N. F. Isa, and S. Shahidan, "Experimental Study of Slurry Infiltrated Fiber 
Reinforced Concrete," Mater. Sci. Forum, vol. 857, pp. 363-366, (2016).

6. Shafigh, P., Mahmud, H. Bin, Jumaat, M. Z., \& Zargar, M. (2014). Agricultural wastes as aggregate in concrete mixtures - A review. Construction and Building Materials, 53,110-117. doi:10.1016/j.conbuildmat.2013.11.074

7. S. Shahidan, I. Isham, and N. Jamaluddin, “A Review on Waste Minimization by Adopting in Self Compacting Concrete," MATEC Web Conf., vol. 47, pp. 1-7, (2016).

8. Yerramala, A. (2012). Properties of Concrete with Coconut Shells as Aggregate Replacement, 1(6), 2131 .

9. Gunasekaran, K., Annadurai, R., \& Kumar, P. S. (2013). Study on reinforced lightweight coconut shell concrete beam behavior under flexure. Materials \& Design, 46, 157-167. doi:10.1016/j.matdes.2012.09.044

10. Gunasekaran, K., Annadurai, R., \& Kumar, P. S. (2012). Long term study on compressive and bond strength of coconut shell aggregate concrete.

11. I. Ismail, N. Jamaluddin, and S. Shahidan, "A Review on Performance of Waste Materials in Self Compacting Concrete (SCC)," J. Teknol., vol. 5, no. 78, pp. 29-35, (2016).

12. Kambli, P. S., \& Mathapati, S. R. (2014). Application of Coconut Shell as Coarse Aggregate in Concrete: A Technical Review, 4(3), 498-501.

13. Chanap, R. (2012). Study of Mechanical and Flexural Properties of Coconut Shell Ash Reinforced Epoxy Composites Bachelor of Technology in Mechanical Engineering BY, (May), 1-41

14. T. U. Ganiron, "Sustainable management of waste coconut shells as aggregates in concrete mixture," $J$. Eng. Sci. Technol. Rev., vol. 6, no. 5, pp. 7-14, (2013).

15. S. Shahidan, H. B. Koh, A. M. S. Alansi, and L. Y. Loon, "Strength Development and Water Permeability of Engineered Biomass Aggregate Pervious Concrete," MATEC Web Conf., vol.47, pp. 2-7, (2016).

16. Gunasekaran, K., Kumar, P.S. \& Lakshmipathy, M., Mechanical and bond properties of coconut shell concrete. Construction and Building Materials, 25(1), pp.92-98 (2011)

17. Gunasekaran, K. et al., Study on reinforced lightweight coconut shell concrete beam behavior under torsion. Materials and Design, 57, pp.374-382 (2014).

18. S. Shahidan, R. Pullin, K. M. Holford, M. B. N, and N. Nor, "Quantitative Evaluation of the Relationship between Tensile Crack and Shear Movement in Concrete beams," Adv. Mater. Res., vol. 626, pp. 355-359, (2013). 